\title{
Perancangan Purwarupa Sistem Informasi Online Pendistribusian dan Persediaan Logistik Saat Tanggap Darurat Bencana di BPBD Pidie Jaya
}

\author{
Zulfadli1 ${ }^{, *}$, Nizamuddin $^{2}$, Nasaruddin ${ }^{3}$ \\ ${ }^{1,2,3}$ Program Studi Magister Ilmu Kebencanaan, Universitas Syiah Kuala \\ Jln. Hamzah Fansuri No 4 Banda Aceh \\ *Koresponden email: zulfadlist@mhs.unsyiah.ac.id
}

Diterima: 20 Maret 2019

Disetujui: 25 Maret 2019

\begin{abstract}
Logistics supply when emergency of disaster comes up that have some problems to be considered such as setting up of emergency operations center irregularly, less coordination between sectors, the data of victims is not properly recorded, and the logistics supply not appropriate with the need of victims. These problems occured because there are no information connected between sectors related to victim data, and the aid that has been fulfilled is very urgent logistics at the disaster site. Information system for distribution and logistics supplies during disaster response is needed to realize effective and efficient distribution. This information system design includes planning, system analysis, collecting data, system design, system testing and implementation. This research was conducted at BPPD office in Pidie Jaya Regency. This information distribution and logistics inventory system that is designed will simplify and accelerate the process of recording in distribution and logistics supply. The results of this system can be introduced to society, so that when disaster occurs the community will receive information quickly and accurately related to distribution and logistics supply.
\end{abstract}

Keywords: Information Systems, Distribution and logistics supply, Emergency response

\begin{abstract}
Abstrak
Pendistribusian logistik pada saat tanggap darurat bencana terdapat beberapa permasalahan yang perlu diperhatikan, diantaranya yaitu tidak beraturannya pendirian posko, kurangnya koordinasi dengan lintas sektor, data para korban tidak tercatat dengan baik, dan proses pendistribusian logistik tidak sesuai dengan kebutuhan para korban di lokasi bencana. Permasalahan tersebut terjadi karena tidak ada informasi terkoneksi ke lintas sektor terkait data korban, bantuan yang telah terpenuhi hingga logistik yang sangat mendesak di lokasi bencana. Sistem informasi pendistribusian dan persediaan logistik pada saat tanggap darurat bencana sangat diperlukan untuk mewujudkan pendistribusian yang efektif dan efesien. Perancangan sistem informasi ini meliputi perencanaan, analisis sistem, pengumpulan data, desain sistem, pengujian terhadap sistem dan penerapan. Penelitian ini dilakukan pada kantor BPPD Kabupaten Pidie Jaya. Sistem informasi pendistribusian dan persediaan logistik yang dibangun ini akan mempermudah dan mempercepat proses pencatatan pendistribusian dan persediaan logistik. Hasil daripada sistem ini nantinya bisa diperkenalkan untuk masyarakat luas, sehingga ketika ada bencana masyarakat akan menerima informasi terkait pendistribusian dan persediaan logistik secara cepat dan akurat.
\end{abstract}

Kata Kunci: Sistem Informasi, Pendistribusian dan persediaan logistik, Tanggap Darurat

\section{Pendahuluan}

Bencana merupakan kejadian atau peristiwa yang mengancam kehidupan dan penghidupan manusia sehingga menimbulkan korban jiwa, kerugian harta benda, kerusakan lingkungan dan juga dampak trauma atau psikologis, yang disebabkan oleh faktor alam, non alam maupun ulah daripada manusia (UndangUndang Republik Indonesia Nomor 24 Tahun 2007). Gempa bumi, tsunami, gunung meletus dan banjir merupakan bencana yang silih berganti terjadi di wilayah Indonesia. Kerusakan, kehilangan harta benda hingga korban jiwapun terus meningkat. Gempa bumi dan tsunami dikategorikan kedalam bencana dengan skala besar, dimana proses penangananpun harus dilakukan secara cepat karena memiliki dampak jauh lebih besar terhadap masyarakat (Jiang et al., 2012).

Pada tahun 2004, Aceh mengalami gempa bumi dan tsunami yang cukup dahsyat dengan magnetudo 9,1 SR, pada kedalaman $250 \mathrm{KM}$ barat daya propinsi Aceh, sebanyak 126.741 korban jiwa, 93.285 orang 


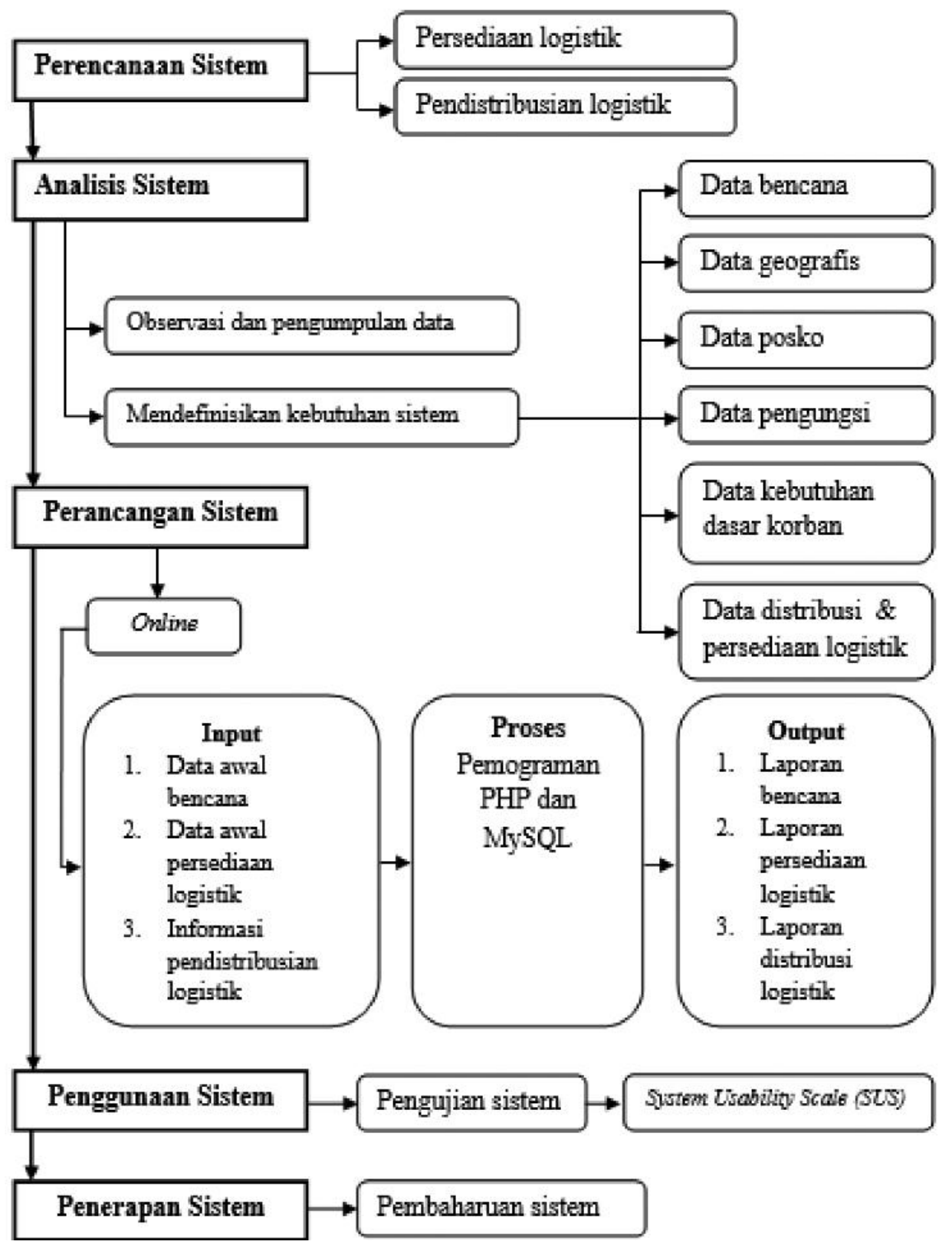

Gambar 1. Desain penelitian

dinyatakan hilang, dan sekitar 500.000 orang kehilangan hunian (Syahbudin et al., 2009). Pada tahun 2013 salah satu Kabupaten di Aceh mengalami goncangan dahsyat yaitu gempa bumi yang terjadi di Kabupaten Aceh Tengah dengan magnetudo 6,2 SR, gempa tersebut mengakibatkan 39 orang meninggal dan lebih 400 orang luka-luka (Hidayati and Irawan, 2014). Kemudian pada tanggal 7 Desember 2016, terjadi gempa bumi tektonik di Kabupaten Pidie Jaya, yang berhasil direkam oleh Badan Meteorologi, Klimatologi dan Geofisika (BMKG) sekitar pukul 05:03:35 WIB, Pusat gempa terletak pada $5.25^{\circ} \mathrm{LU}$ dan $96.24^{\circ} \mathrm{BT}$ dengan magnitudo 6,5
SR pada kedalaman $10 \mathrm{~km}$. Gempa bumi tersebut berpusat didarat dan tidak mengakibatkan tsunami (Release BMKG, 2016). Gempa berdampak pada tiga kabupaten yaitu Kabupaten Pidie Jaya, Pidie dan Bireun. Gempa tersebut menyebabkan 104 orang meninggal dunia (Pidie Jaya 97 Orang, Pidie 5 Orang dan Bireun 2 Orang), 186 jiwa luka berat, 789 luka ringan, serta menimbulkan kerusakan pada sektor permukiman, infrastruktur, ekonomi, sosial dan lintas sektor (BNPB, 2017).

Pada saat bencana, Badan Penanggulangan Bencana Daerah (BPBD) berperan penting dalam menyukseskan proses tanggap darurat bencana, 
baik itu bencana dengan skala besar maupun skala kecil (Shinya and Widjaja, 2015). BPBD bertugas dalam mengkoordinasikan pelaksanaan kegiatan penanggulangan bencana secara terencana, terpadu dan menyeluruh (Permendagri 46, 2008). sistem informasi terkait pendistribusian dan persediaan logistik sangat diperlukan, untuk memudahkan dan memperlancar proses penyaluran kebutuhan dasar korban yang berada di tempat pengungsian. Oleh karena itu, setiap keadaan darurat seharusnya proses penanganan terkait penyaluran logistik itu menggunakan sebuah aplikasi (Raich et al., 2014). Sistem pendistribusian dan persediaan logistik yang efesien memegang peranan penting dalam menjaga dan mengelola aliran pasokan dan penyaluran logistik kepada korban yang berada di tempat pengungsian supaya dapat mengurangi dampak buruk yang ditimbulkan (Ozguven and Ozbay, 2013).

Dari hasil pengamatan dan pengalaman peneliti pada saat aksi respon cepat tanggap darurat gempa bumi Pidie Jaya, banyak kendala yang dihadapi dilapangan dalam proses penyaluran logistik sehingga menyebabkan logistik tidak terdistribusi dengan baik, mulai dari tidak beraturannya pendirian posko. Keterlambatan penyaluran logistik juga disebabkan karena kurangnya koordinasi dengan lintas sektor dalam proses pendistribusian, sehingga pada saat respon cepat tanggap darurat ada beberapa wilayah yang tidak terdistribusi khususnya untuk pemenuhan kebutuhan dasar korban. Tidak adanya sistem informasi logistik yang terintegrasi juga mengakibatkan pemenuhan kebutuhan dasar korban tidak sesuai dengan kondisi riil pengungsi. Tidak adanya data kebutuhan dasar masyarakat yang terdampak dan terbatasnya informasi persediaan logistik di gudang atau posko induk, sehingga pihak donatur mengalami kesulitan dalam menentukan kebutuhan yang sangat mendesak dilapangan.

Pada saat tanggap darurat gempa bumi Pidie Jaya, pihak BPBD belum mempunyai aplikasi untuk mencatat proses pendistribusian dan persediaan logistik yang bisa diakses dengan mudah oleh masyarakat luas, maka oleh sebab itu penulis akan merancang sebuah aplikasi pendistribusian dan persediaan loigistik secara online.

\section{Metodologi Penelitian}

Desain penelitian dalam penulisan inimenggunakan pendekatan Research and Development (penelitian dan pengembangan), dimana penelitian ini akan terus dikembangkan sampai ke tahap yang lebih sempurna.

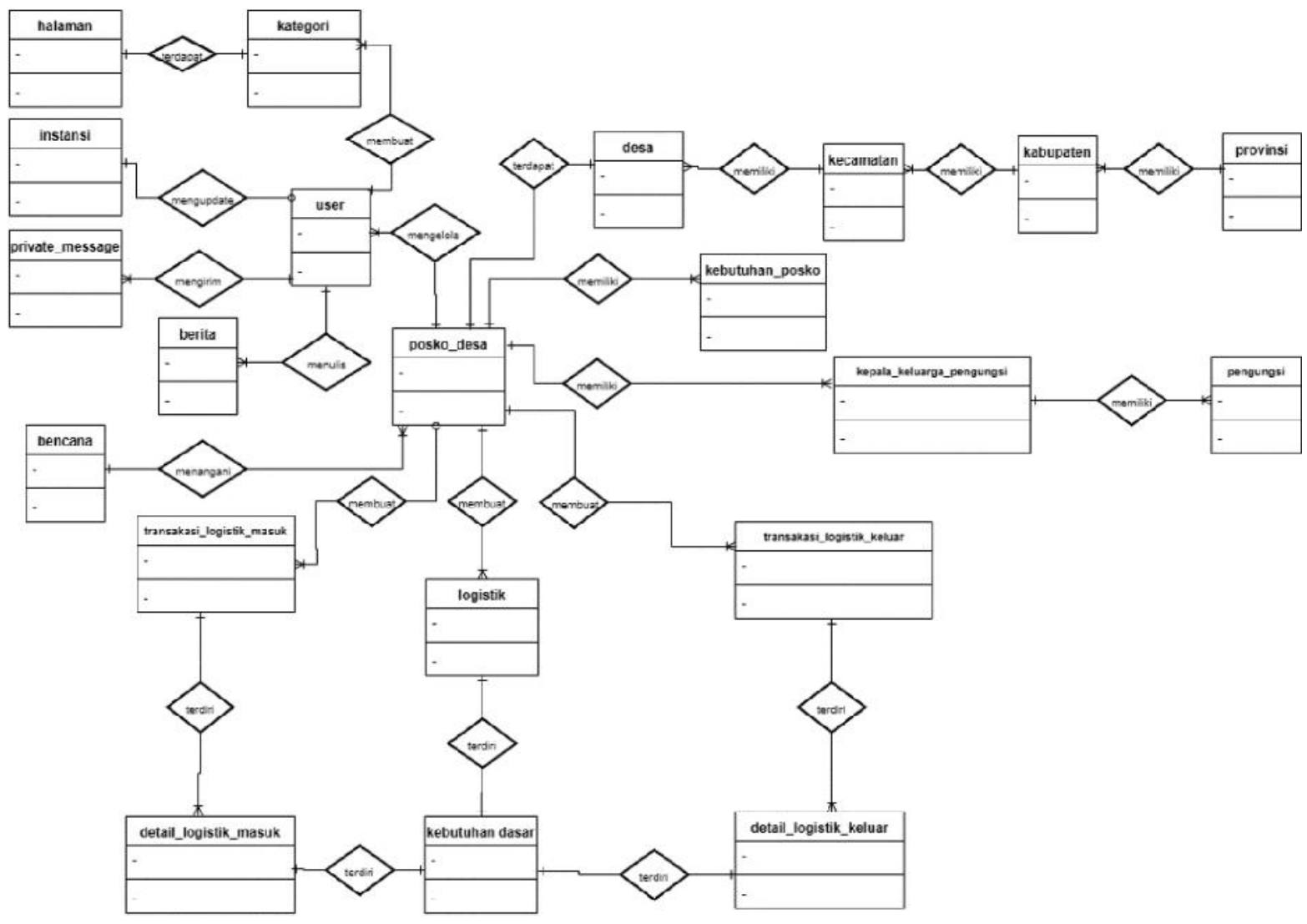

Gambar 2. Entity Relationship Diagram 


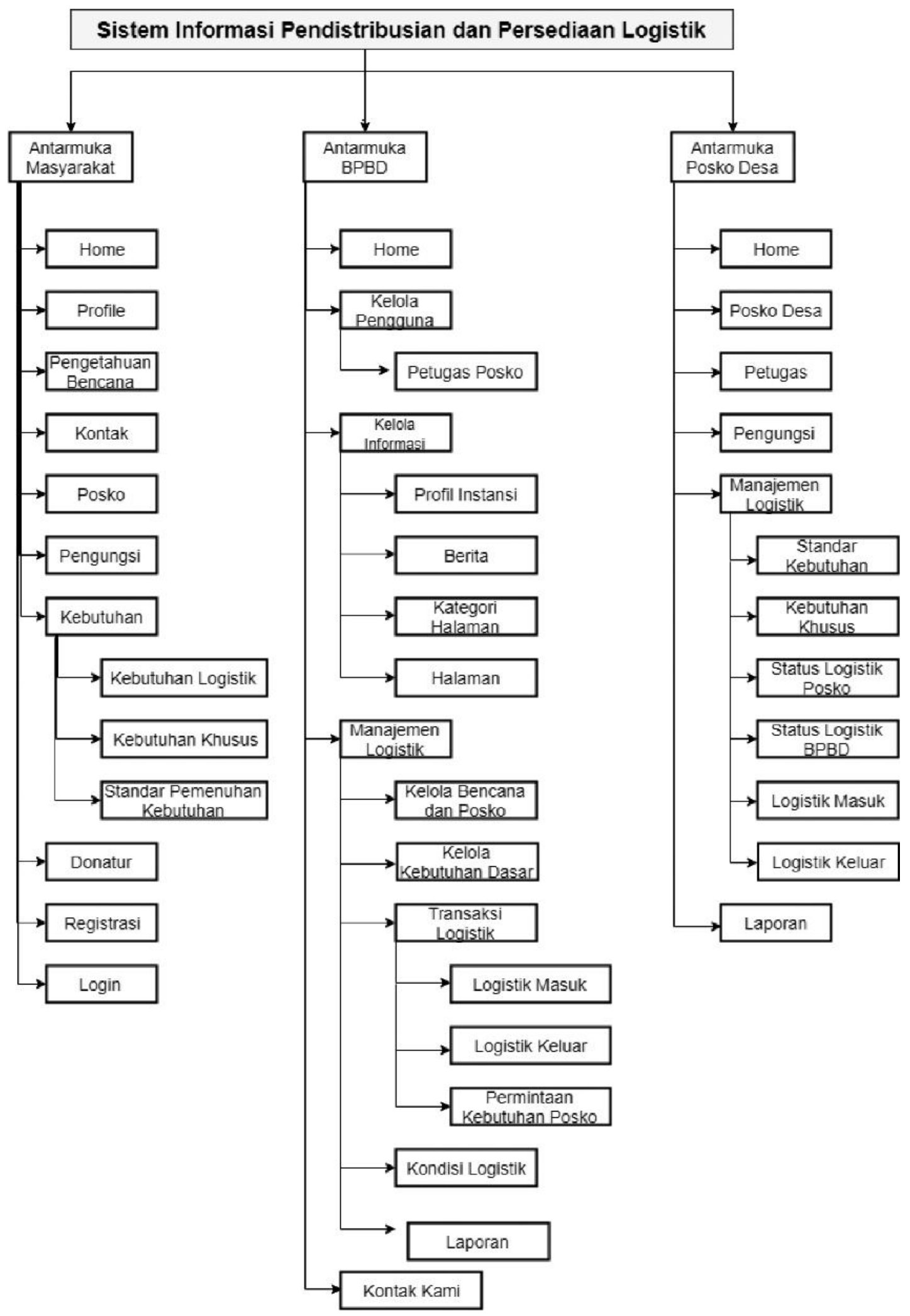

Gambar 3. Arsitektur sistem

1. Perencanaan sistem

Perencanaan sistem merupakan langkah awal untuk merumuskan dan mengidentifikasi kebutuhankebutuhan terhadap suatu sistem, dimana ditahapan ini penulis melakukan perumusan seperti merencanakan bagaimana sistem bisa mencatat proses pendistribusian logistik dan mengelola persediaan logistik di posko. Perencanaan sistem bertujuan untuk mengidentifikasi 
Sistem Informasi Pendistribusian Dan Persediaan Logistik BP8O Kabupaten Pidie Jaya

A Home $\quad$ - Proni $\star$ Rengelahuan Bencana $A$ Kontak
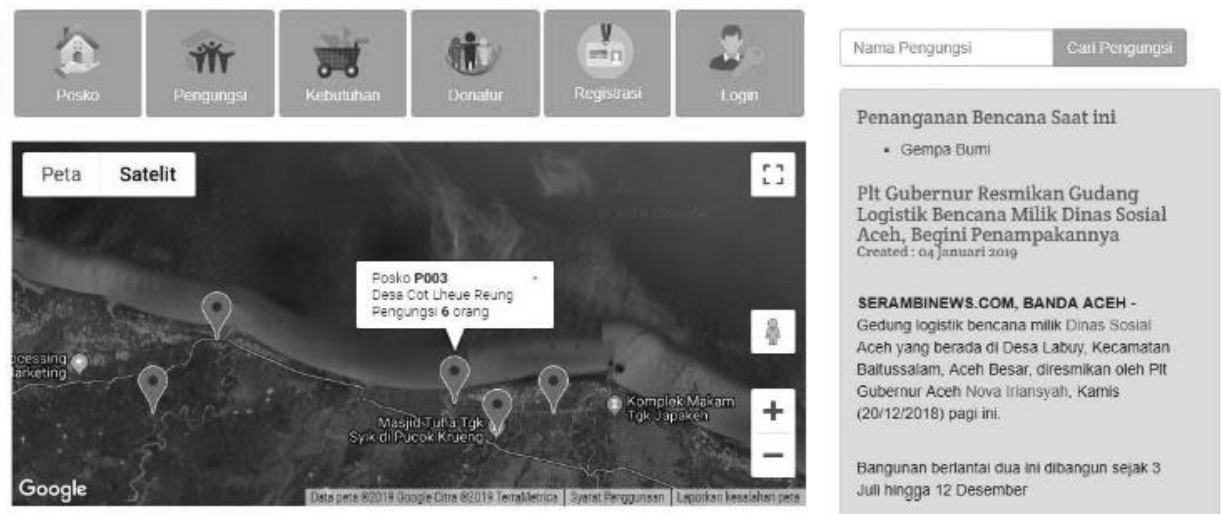

Sistem Intornast Pendistnbusian Dan Persediaan Logistik 92019 BPBD Kabupaten Pidke Jaya

Gambar 4. Halaman utama

sasaran yang akan dicapai (Yakub, 2012).

2. Analisis sistem

Analisis sistem merupakan penguraian bagianbagian komponen yang berinteraksi untuk mencapai suatu tujuan dengan teknik pemecahan masalah (Al Fatta, 2007). Tahapan analisis sistem menjadi hal yang sangat berpengaruh dalam menentukan keberhasilan suatu sistem. Pada tahapan ini penulis akan melakukan observasi dan pengumpulan datadata yang dibutuhkan oleh sistem.

3. Perancangan sistem

Tahapan ini merupakan tahapan penyempurnaan kebutuhan yang masih berupa konsep menjadi suatu sistem yang riil (Al Fatta, 2007). Pada tahapan ini penulis akan mengubah konsep-konsep yang sudah ada untuk diterapkan menjadi satu kesatuan yang utuh dan berfungsi dengan penggambaran, perencanaan dan pembuatan sketsa (Yakub, 2012).

4. Penggunaan Sistem

Penggunaan sistem merupakan tahapan dimana penulis akan mencoba mengimplementasikan sistem yang telah dirancang dengan bahasa pemrograman untuk dapat digunakan. Dalam tahapan ini penulis juga akan melakukan pengujian sistem dengan menggunakan metode pengujian System Usability Scale (SUS) untuk melihat efektivitas penggunaan aplikasi.

5. Penerapan sistem

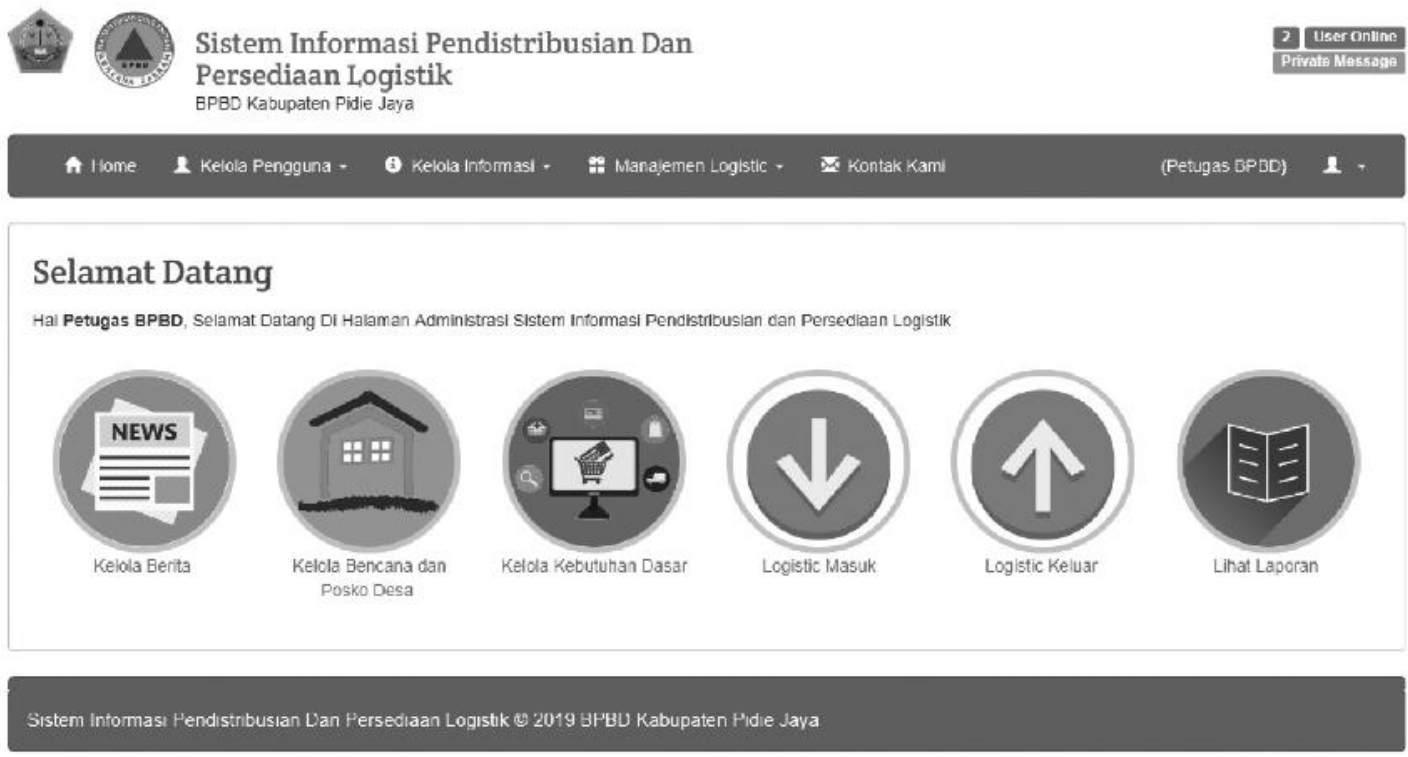

Gambar 5. Halaman utama BPBD 


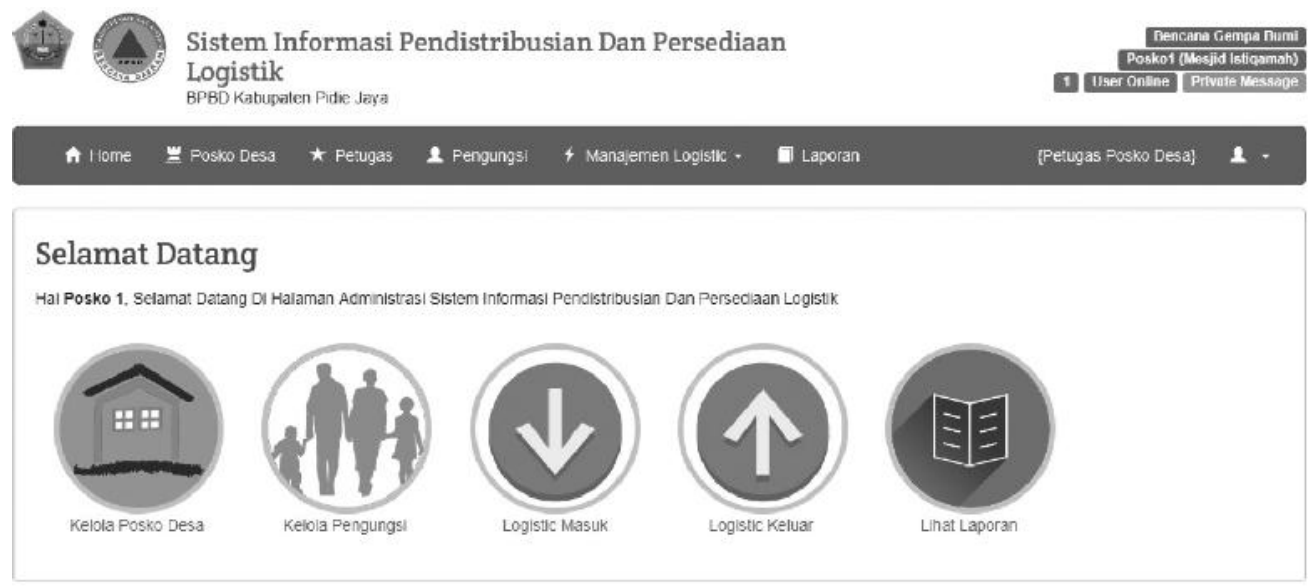

Sistem Infrmasi Pendistibusian Dan Persedian Lojistik 22019 BPED Kabupaten Pidie Jiva

Gambar 6. Halaman utama posko desa

Penerapan sistem merupakan proses dimana sistem akan dijalankan pada suatu instansi atau lembaga yang terkait, dalam penelitian ini akan melakukan penerapan sistem pada BPBD Pidie Jaya.

\section{Hasil Dan Pembahasan}

Perancangan purwarupa sistem informasi online pendistribusian dan persediaan logistik pada saat tanggap darurat bencana di BPBD Pidie Jaya dibangun dengan menggunakan bahasa pemrograman PHP: Hypertext Preprocessor yang digunakan untuk membuat halaman web dinamis, yang didukung oleh software Macromedia Dreamweaver 8 sebagai tempat untuk menulis kode atau perintah pemrograman, dan juga didukung oleh software Xampp v.3.2.2 yang berfungsi sebagai server yang berdiri sendiri (localhost).

\subsection{Desain Proses}

\section{Entity Relationship Diagram (ERD)}

Entity Relationship Diagram (ERD) merupakan diagram yang menunjukkan hubungan atar entitas yang relevan dalam suatu sistem (Kristanto, 2008 dalam Afyenni, 2014). Entitas merupakan proses pengumpulan data yang dilakukan untuk menghasilkan suatu informasi sebagai pendukung sebuah sistem. Entitas yang terlibat serta relasi yang muncul disini

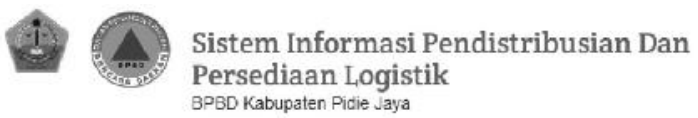

Sistem Informasi Pendistribusian Dan
Persediaan Logistik BPBD Kabupaten Pidie Jaya

\section{A Ilore 2 Kelola Fengguna , o kenla Intermasi - if Manajemen Logistic - ¿ Kontak Karmi}

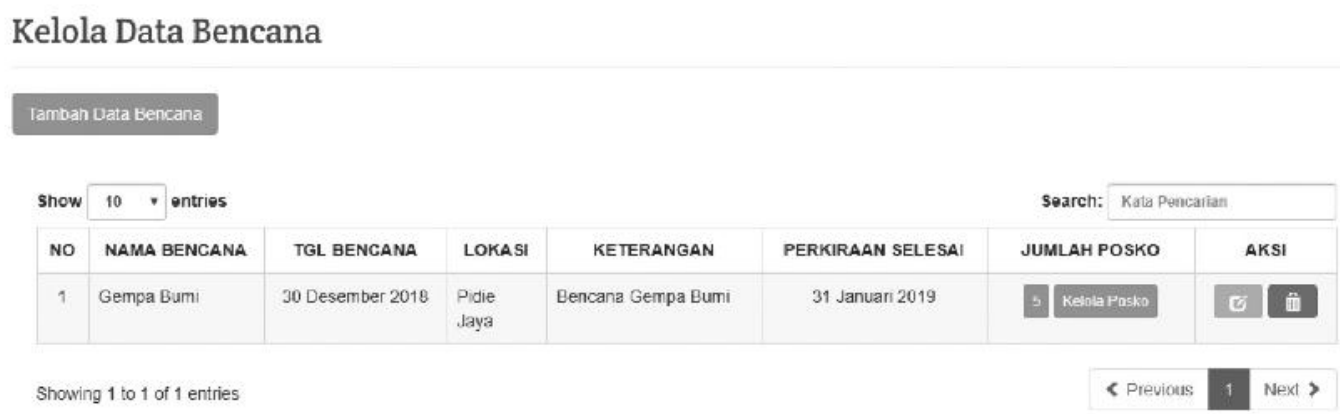

Sistem Informasi Pendistribusian Dan Persediaan Logistik @ 2019 BPBD Kabupaten Pidic Jaya

Gambar 7. Halaman kelola bencana 


\section{Kembali}

Kelola Posko Desa Bencana Gempa Bumi

\section{Tanhisi Pasko Desa}

\begin{tabular}{|c|c|c|c|c|c|c|c|c|}
\hline show & 10 Pentries & & & \multicolumn{5}{|c|}{ Search: Kata Pesicarian } \\
\hline no & KODE POSKO & NAMA POSKO & ALAMAT POSKO & \multicolumn{3}{|c|}{ DATA POSKO } & \multicolumn{2}{|c|}{ AKSI POSKO } \\
\hline 1 & P001 & Posk01 (Mesid Isliqamah) & Desa rieng Blang & 12 Pilluges: & 3 1 Fow & \# $\log$ ilic & E & in \\
\hline 2 & г002 & Posko2 (Mcucet rengwa) & Dcsa Meucat rengwa & 12 pedues & 22 rencungs & Ex Loustic & E & A \\
\hline 3 & Poos & Poska3 (Cot Lreup Reung) & Desa Cxh Lreve fieung & 12 Poluper & $6 \perp$ Fovanges & \# Lovitit & $E$ & 音 \\
\hline 4 & Poos & Poskod (Keude Parte Raja) & Desa Keuce Parte raa & 12 Pahigar & 0.2 tanganga & Elogstac. & e & if \\
\hline s & POL & Poskats (Hang Haru) & Desa Hiang bau & 12 Polusere & o. 1 Furesunges & A Lowelit & E & i \\
\hline
\end{tabular}

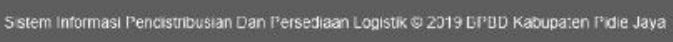

Gambar 8. Halaman kelola posko desa

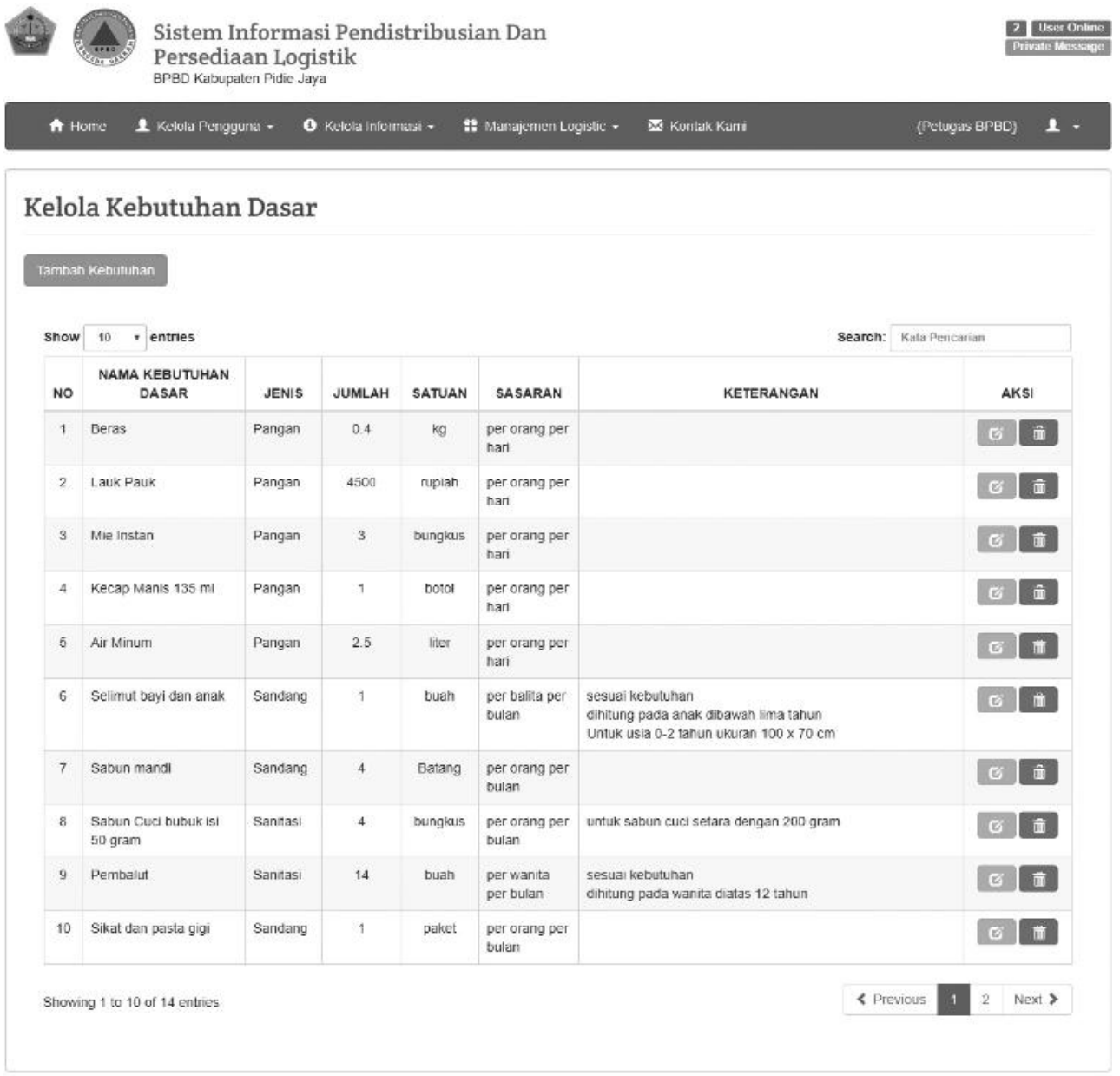

Sistem Informasi Pendistribusian Dan Fersediaan L mgistik (B) 2019 BГBD Kabupaten Pidie Jaya

Gambar 9. Halaman kelola kebutuhan dasar 


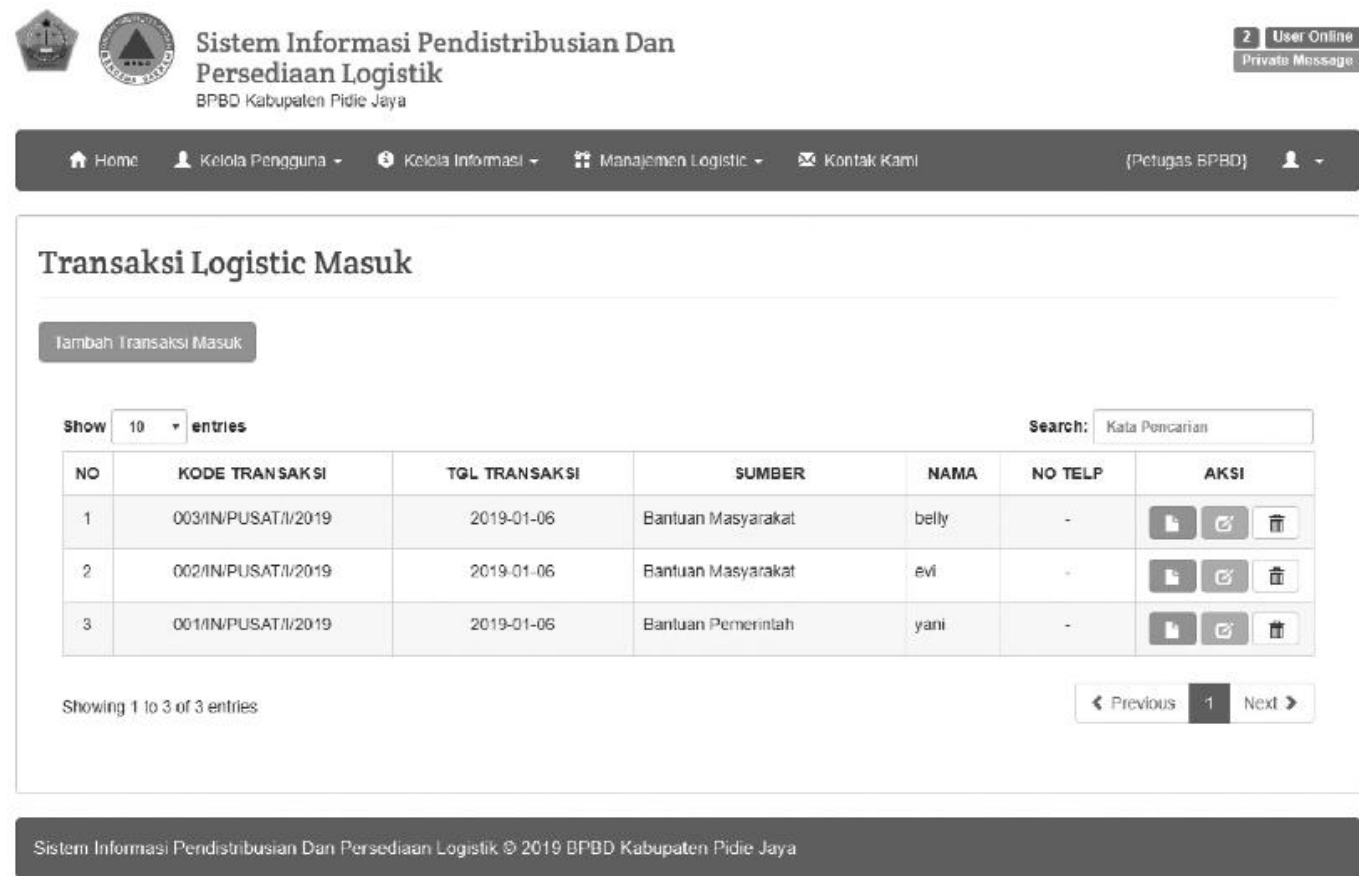

Gambar 10. Halaman logistik masuk

selanjutnya akan dipakai dalam merancang kebutuhan database yang diperlukan. ERD sistem informasi pendistribusian dan persediaan logistik dapat dilihat pada Gambar 2.

\section{Arsitektur Sistem}

Arsitektur sistem merupakan gambaran untuk merencanakan pengembangan sebuah sistem
(Kurniawan, 2013). Arsitektur dibuat untuk mempermudah proses perancangan dari pada sistem tersebut. Sistem yang dirancang ini terbagi dalam 3 bagan yaitu: antarmuka masyarakat, antarmuka BPBD dan antarmuka posko. Adapun arsitektur sistem informasi pendistribusian dan persediaan logistik dapat dilihat pada Gambar 3.

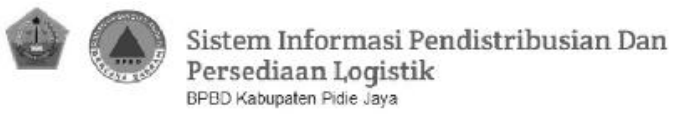

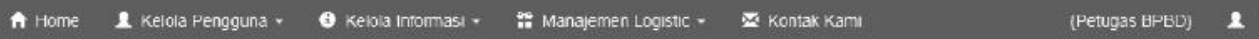

Transaksi Logistic Keluar

\section{Tambah Transaksi Keluar}

\begin{tabular}{|c|c|c|c|c|c|c|c|c|c|}
\hline show & $10 \quad r$ entries & & & & & Search: & enca & & \\
\hline NO & KODE TRANSAKSI & TGL TRANSAKSI & TUJUAN & BENCANA & PENERIMA & NO TELP & & AKSI & \\
\hline 1 & DO1/OUTIPUSATM/2019 & $2018-12-30$ & Distribusi Pengungsi & Gempa Bumi & Ramulah & & L & 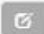 & tit \\
\hline 2 & 001/OUTIFUSAT//2019 & $2018-12-30$ & Distribusi Pasko & Gempa Buml & jamilan & & t & $\sigma$ & tี \\
\hline 3 & 001/OUT/PUSAT//2019 & $2010-12-30$ & Distribusi Pengungsi & Gempa Buml & Nani & - & E & E & iit \\
\hline 4 & O01/OUT/PUSATA/2D19 & $2018-12-30$ & Distribusi Pengungsi & Gempa Bumi & bell & - & $\boldsymbol{B}$ & 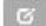 & 鱼 \\
\hline
\end{tabular}

Sisterm Informasi Pendistribusian Dan Persediaan Logistik O 2019 BPBD Kabupaten Pidie Jaya

Gambar 11. Halaman logistik keluar 

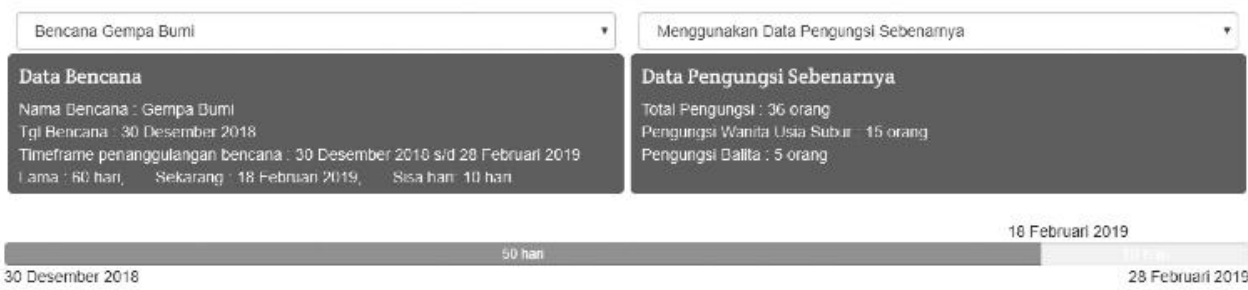

Kebutuhan Dasar

\begin{tabular}{|c|c|c|c|c|c|c|c|c|c|c|}
\hline NO & $\begin{array}{l}\text { NAMA } \\
\text { KEBUTUHAN }\end{array}$ & JENIS & KEBUTUHAN & $\begin{array}{l}\text { PENGUNGSI } \\
\text { TOTAL }\end{array}$ & $\begin{array}{l}\text { JUMLAH } \\
\text { KEBUTUHAN } \\
10 \text { HARI }\end{array}$ & $\begin{array}{l}\text { TERSEDIA DI } \\
\text { GUDANG }\end{array}$ & $\begin{array}{l}\text { TERSEDIA DI } \\
\text { POSKO }\end{array}$ & KURANG & LEBIH & SATUAN \\
\hline 1 & Beras & Pangan & $\begin{array}{l}0.4 \mathrm{~kg} \text { per orang } \\
\text { per hari }\end{array}$ & 36 & 144 & 190 & 13 & & 59 & $\mathrm{~kg}$ \\
\hline 2 & Lauk Pauk & Pangan & $\begin{array}{l}4500 \text { rupiah per } \\
\text { orang per harl }\end{array}$ & 36 & $1,620,000$ & 900,000 & 90,000 & 630,000 & & rupiah \\
\hline 3 & Mie instan & Pangan & $\begin{array}{l}3 \text { bungkus per } \\
\text { orang per han }\end{array}$ & 36 & 1.080 & 90 & 18 & 972 & & bungkus \\
\hline 4 & $\begin{array}{l}\text { Kecap Manis } 135 \\
\mathrm{ml}\end{array}$ & Pangan & $\begin{array}{l}1 \text { botol per orang } \\
\text { per hari }\end{array}$ & 36 & 360 & 90 & 8 & 262 & & Dotol \\
\hline 5 & Air Minum & Pangan & $\begin{array}{l}2.5 \text { iter per orang } \\
\text { per harl }\end{array}$ & 36 & 900 & 1,000 & 0 & & 100 & liter \\
\hline 6 & $\begin{array}{l}\text { Selimut bayi dan } \\
\text { anak }\end{array}$ & Sandang & $\begin{array}{l}1 \text { buan per balita } \\
\text { per bulan }\end{array}$ & 5 & 5 & 10 & 10 & & 15 & buah \\
\hline 7 & Sabun mandı & Sandang & $\begin{array}{l}4 \text { Batang per orang } \\
\text { per bulan }\end{array}$ & 36 & 144 & 100 & 0 & 44 & & Eatang \\
\hline 8 & $\begin{array}{l}\text { Sabun Cuci bubuk } \\
\text { Is! } 50 \text { gram }\end{array}$ & Sanitasi & $\begin{array}{l}4 \text { bungkus per } \\
\text { orang per buan }\end{array}$ & 36 & 144 & 0 & 0 & 144 & & bungkus \\
\hline 9 & Pembalut & Sanitas! & $\begin{array}{l}14 \text { buah per wanita } \\
\text { per bulan }\end{array}$ & 15 & 210 & 0 & 0 & 210 & & buan \\
\hline 10 & $\begin{array}{l}\text { Sikat dan pasta } \\
\text { gigi }\end{array}$ & Sandang & $\begin{array}{l}1 \text { paket per orang } \\
\text { per bulan }\end{array}$ & 36 & 36 & 100 & 0 & & 64 & paket \\
\hline 11 & Air bersinh & Sanitasi & $\begin{array}{l}15 \text { liter per orang } \\
\text { per harl }\end{array}$ & 36 & 5,400 & 0 & 0 & 5.400 & & inter \\
\hline 12 & Pakalan Lengkap & Sandang & $\begin{array}{l}1 \text { Paket per orang } \\
\text { per butan }\end{array}$ & 36 & 36 & 100 & 0 & & 64 & Paket \\
\hline 13 & Sumbangan & Pangan & $\begin{array}{l}5000 \text { Rupiah per } \\
\text { orang per hari }\end{array}$ & 36 & $1,800,000$ & $2,000,000$ & 200,000 & & 400,000 & Ruplah \\
\hline
\end{tabular}

Gambar 12. Halaman status kondisi logistik

\subsection{Implementasi}

Berikut ini ada beberapa contoh hasil dari implementasi sistem informasi online pendistribusian dan persediaan logistik pada saat bencana di BPBD Pidie Jaya.

\section{Halaman utama}

Gambar 4. merupakan halaman utama bagi masyarakat untuk melihat dan mengakses beberapa data terkait pendistribusian dan persediaan logistik pada saat tanggap darurat bencana, dimana dengan adanya akses ini akan mempermudah siapapun melacak kondisi logistik di lokasi bencana. Adapun data yang bisa diakses adalah sebagai berikut:

a. Data posko desa yang telah terdaftar di sistem

b. Data pengungsi yang terdaftar di setiap posko

c. Data kebutuhan logistik pada saat tanggap darurat

d. Data donatur yang telah menyalurkan bantuan logistik

\section{Halaman utama BPBD}

Gambar 5. merupakan halaman awal bagi petugas BPBD untuk mengelola informasi terkait tanggap darurat bencana. Dihalaman ini petugas BPBD bisa melakukan proses pengelolaan berita, pengelolaan bencana, pengaktifan posko desa, pencatatan transaksi logistik masuk, logistik keluar membuat laporan.

\section{Halaman utama posko desa}

Gambar 6. merupakan halaman petugas posko desa akan melakukan proses pengelolaan posko desa, pengelolaan pengungsi, pencatatan transaksi logistik masuk, logistik keluar dan membuat laporan yang dibutuhkan.

\section{Halaman kelola bencana}

Gambar 7. merupakan halaman yang disediakan oleh sistem untuk mengelola bencana. Di halaman 


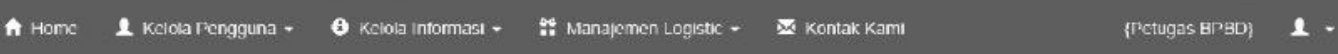

\section{Laporan}

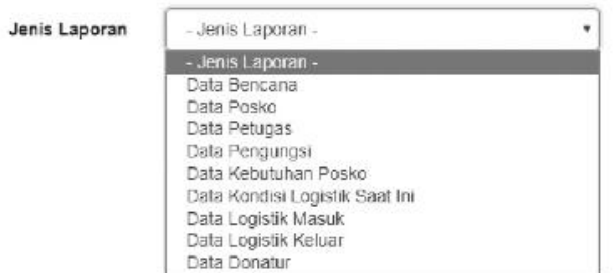

Sistem Informasi Pendistrbusian Dan Persediaan Logistik 2019 BPBu Kabupaten Prdie Jaya

Gambar 13. Halaman lihat laporan

ini petugas BPBD akan melakukan penginputan dan pengaktifan tanggap darurat bencana.

5. Halaman kelola posko desa

Gambar 8. merupakan halaman yang digunakan oleh petugas BPBD untuk melakukan pencatatan data petugas posko desa dan pengaktifan posko desa dilokasi pengungsi. Petugas posko desa akan bertanggung jawab penuh terhadap proses penginputan transkasi logistik masuk dan keluar.

6. Halaman kelola kebutuhan dasar

Tabel 1. Hasil rekap kuisioner SUS

\begin{tabular}{|c|c|c|c|c|c|c|c|c|c|c|c|c|}
\hline & \multicolumn{11}{|c|}{ Pertanyaan } & \multirow{2}{*}{ Total SUS } \\
\hline & & 1 & 2 & 3 & 4 & 5 & 6 & 7 & 8 & 9 & 10 & \\
\hline \multirow{22}{*}{ Responden } & 1 & 10 & 10 & 7,5 & 5 & 10 & 10 & 7,5 & 10 & 7,5 & 7,5 & 85,00 \\
\hline & 2 & 7,5 & 7,5 & 10 & 7,5 & 10 & 10 & 10 & 10 & 7,5 & 5 & 85,00 \\
\hline & 3 & 10 & 7,5 & 10 & 5 & 10 & 10 & 10 & 10 & 7,5 & 7,5 & 87,50 \\
\hline & 4 & 10 & 7,5 & 10 & 7,5 & 10 & 10 & 10 & 10 & 7,5 & 7,5 & 90,00 \\
\hline & 5 & 7,5 & 2,5 & 7,5 & 0 & 10 & 7,5 & 7,5 & 5 & 7,5 & 0 & 55,00 \\
\hline & 6 & 10 & 10 & 10 & 7,5 & 10 & 10 & 10 & 10 & 10 & 10 & 97,50 \\
\hline & 7 & 7,5 & 7,5 & 7,5 & 5 & 7,5 & 7,5 & 10 & 10 & 7,5 & 5 & 75,00 \\
\hline & 8 & 7,5 & 5 & 7,5 & 5 & 10 & 10 & 10 & 7,5 & 5 & 5 & 72,50 \\
\hline & 9 & 5 & 5 & 7,5 & 5 & 10 & 10 & 7,5 & 7,5 & 5 & 5 & 67,50 \\
\hline & 10 & 7,5 & 7,5 & 7,5 & 5 & 10 & 10 & 7,5 & 7,5 & 7,5 & 5 & 75,00 \\
\hline & 11 & 10 & 7,5 & 10 & 5 & 10 & 7,5 & 7,5 & 7,5 & 7,5 & 5 & 77,50 \\
\hline & 12 & 5 & 5 & 7,5 & 5 & 7,5 & 10 & 7,5 & 10 & 7,5 & 5 & 70,00 \\
\hline & 13 & 10 & 10 & 10 & 5 & 10 & 10 & 10 & 7,5 & 7,5 & 5 & 85,00 \\
\hline & 14 & 7,5 & 5 & 10 & 5 & 10 & 10 & 10 & 10 & 10 & 5 & 82,50 \\
\hline & 15 & 5 & 7,5 & 10 & 10 & 10 & 10 & 5 & 7,5 & 10 & 2,5 & 77,50 \\
\hline & 16 & 10 & 7,5 & 10 & 5 & 7,5 & 10 & 7,5 & 7,5 & 7,5 & 7,5 & 80,00 \\
\hline & 17 & 7,5 & 7,5 & 7,5 & 2,5 & 7,5 & 7,5 & 10 & 7,5 & 7,5 & 5 & 70,00 \\
\hline & 18 & 7,5 & 7,5 & 10 & 2,5 & 10 & 10 & 10 & 10 & 7,5 & 5 & 80,00 \\
\hline & 19 & 10 & 10 & 10 & 7,5 & 10 & 10 & 10 & 10 & 7,5 & 5 & 90,00 \\
\hline & 20 & 7,5 & 7,5 & 10 & 5 & 7,5 & 7,5 & 10 & 10 & 7,5 & 5 & 77,50 \\
\hline & 21 & 7,5 & 5 & 7,5 & 5 & 7,5 & 10 & 7,5 & 7,5 & 5 & 5 & 67,50 \\
\hline & 22 & 7,5 & 7,5 & 7,5 & 5 & 10 & 7,5 & 10 & 7,5 & 7,5 & 5 & 75,00 \\
\hline & & & & & & OTA & & & & & & $\mathbf{1 7 2 2 , 5 0}$ \\
\hline & & & a-R & Nila & US ( & tal S & $/ \mathbf{J}$ & ah R & gond & & & 78,30 \\
\hline
\end{tabular}


Gambar 9. merupakan halaman tempat penginputan standar bantuan logistik untuk para korban pada saat tanggap darurat. Di halaman ini petugas BPBD akan menentukan jenis dan jumlah kebutuhan dasar logistik yang disalurkan untuk setiap korban di pengungsian.

7. Halaman logistik masuk

Gambar 10. merupakan halaman dimana petugas akan mencatat data transaksi logistik masuk, baik logistik tersebut disalurkan dari pemerintah ataupun bantuan masyarakat.

8. Halaman logistik keluar

Gambar 11. merupakan halaman dimana petugas akan mencatat data transaksi logistik keluar, baik logistik tersebut didistribusikan kepada petugas posko desa maupun masyarakat.

9. Halaman status kondisi logistik

Gambar 12. merupakan halaman untuk melihat data kondisi logistik yang tersedia baik di posko maupun di gudang. Dengan jumlah kondisi pengungsi di posko pengungsian, petugas BPBD dapat dengan mudah mengetahui keadaan logistik yang tersedia dan jumlah logistik yang dibutuhkan untuk korban bencana dalam masa tanggap darurat.

10. Halaman lihat laporan

Gambar 13. merupakan halaman untuk melihat dan mencetak laporan terkait pendistribusian dan persediaan logistik pada saat tanggap darurat bencana. Dihalaman ini petugas dapat mencetak laporan seperti data bencana, data posko, data petugas, data pengungsi, data kebutuhan posko, data kondisi logistik saat ini, data logistik masuk, logistik keluar dan data donatur.

\subsection{Pengujian System Usability Scale (SUS)}

System Usability Scale (SUS) merupakan sebuah metode pengujian yang digunakan untuk menguji sebuah perangkat lunak dengan fasilitas. SUS dapat digunakan dalam melakukan pengujian teknologi yang independen baik pada perangkat keras, perangkat lunak, website dan bahkan perangkat seluler (Sauro, 2011 dalam Ependi et al., 2018).

Pengujian SUS dilakukan untuk mengevaluasi efektifitas sistem terhadap pengguna. SUS diaplikasikan berbentuk kuisioner, dimana didalam kuisioner tersebut terdapat 10 pertanyaan dengan 5 pilihan jawaban mulai dari sangat tidak setuju sampai dengan sangat setuju (Brooke, 1996 dalam Yudha et al., 2017). Pengujian SUS dilakukan dengan melibatkan 22 orang responden dengan 3 kriteria yaitu responden yang mengerti terhadap sistem, staf BPBD Pijay, dan volunteer. Pengujian dilakukan setelah responden melihat penjelasan atau menggunakan langsung sistem tersebut.

Hasil perhitungan evaluasi SUS diperoleh nilai rata-rata 78,30. Hal ini menunjukkan bahwa tingkat penggunaan sistem informasi ini dapat diterima dan sangat mudah digunakan oleh pengguna.

\section{Kesimpulan}

1. Perancangan purwarupa sistem informasi online pendistribusian dan persediaan logistik pada saat tanggap darurat akan mempermudah kinerja lintas sektor dalam proses penanggulangan bencana.

2. Dapat mengetahui jumlah pengungsi dan kebutuhan logistik dalam masa tanggap darurat.

3. Distribusi dan persediaan logistik akan tercatat secara cepat dan akurat

4. Dapat mempermudah proses pencatatan pendistribusian, persediaan dan pelaporan pada saat tanggap darurat bencana.

\section{Saran}

Diharapkan agar BPBD Pidie Jaya untuk mengimplementasikan sistem informasi pendistribusian dan persediaan logistik ini, supaya akan memudahkan proses tanggap darurat saat terjadi bencana.

\section{Daftar Pustaka}

Afyenni, R. 2014 (2014) 'Perancangan Data Flow Diagram untuk Sistem Informasi Sekolah (Studi Kasus Pada SMA Pembangunan Laboratorium UNP)', Teknoif, 2(1), pp. 35-39. doi: 10.1016/ S0021-9517(03)00280-X.

BNPB (2017) 'Informasi Kebencanaan Bulanan Teraktual', pp. 1-4.

Ependi, U., Panjaitan, F. and Hutrianto (2018) 'System Usability Scale Antarmuka Palembang Guide Sebagai Media Pendukung Asian Games XVIII', Journal of Information System Enginnering and Bussines Intellegence, 3(2), pp. 101-107.

Al Fatta, H. (2007) Analisis dan Perancangan Sistem Informasi untuk Keunggulan Bersaing Perusahaan dan Organisasi Modern. Edited by A. Heni Triyuliana. Yogyakarta: ANDI.

Hidayati, S. and Irawan, W. (2014) 'Pengaruh mekanisme sesar terhadap Gempa Bumi Aceh Tengah, 2 Juli 2013 The influence of fault mechanism to the Aceh Tengah's Earthquake on July 2 2013', 5(2), pp. 79-91. 
Jiang, Y. et al. (2012) 'Logistics for Large-Scale Disaster Response: Achievements and Challenges'. doi: 10.1109/HICSS.2012.418.

Kurniawan, H. (2013) 'Perancangan Arsitektur Sistem Informasi Menggunakan Enterprise Arsitecture Planning', Jurnal Informatika, 13(1), pp. 41-51.

Ozguven, E. E. and Ozbay, K. (2013) 'A secure and efficient inventory management system for disasters', Transportation Research Part C, 29, pp. 171-196. doi: 10.1016/j.trc.2011.08.012.

Permendagri 46 (2008) 'Pedoman organisasi dan tata kerja BPBD.pdf'.

Raich, M. et al. (2014) 'Disaster Logistics: The disaster supply chain and the role of human behavior', pp. 1-12. Available at: http://psycris. eu/media/Raich_Prod_Economics.pdf.

Release BMKG, P. (2016) 'Badan meteorologi klimatologidan geofisika', (2), pp. 2-4.

Shinya, T. and Widjaja, B. W. (2015) Memimpin Operasi Tanggap Darurat dalam Bencana Alam Skala Besar. Edited by D. Faoziah et al. Japan International Cooperation Agency (JICA) Indonesia Office Badan Nasional Penanggulangan Bencana (BNPB).

Syahbudin, B. et al. (2009) TSUNAMI: Habis Bencana Terbitlah Terang. Edited by H. Supit. Banda Aceh, NAD: Badan Rehabilitasi dan Rekonstruksi NAD-NIAS.

Yakub (2012) Pengantar Sistem Informasi. Edisi Pert. Yogyakarta: GRAHA ILMU.

Yudha, A. A. N. P., Sudarma, M. and Suyadnya, I. M. A. (2017) 'Rancang Bangun Aplikasi Manajemen Sales Force Berbasis Web Dan Android Dilengkapi Layanan Informasi Geografis', 4(2), pp. 26-35. 